\title{
Ruminal parameters and ruminal degradability of feedlot sheep fed safflower grains
}

\section{Parâmetros ruminais e degradabilidade ruminal de ovinos alimentados com grãos de cártamo em confinamento}

\author{
ALVES, Jefferson Leonardo Rocha ${ }^{1^{*}}$; GOES, Rafael Henrique de Tonissi e Buschinelli \\ $\mathrm{de}^{2}$; MARTINEZ, Antônio Campanha ${ }^{3}$; NAKAMURA, Aguinaldo Yoshio ${ }^{4}$; GANDRA, \\ Jefferson Rodrigues ${ }^{2}$; SOUZA, Luiz Carlos Ferreira de ${ }^{2}$
}

\footnotetext{
${ }^{1}$ Universidade Estadual de Maringá, Centro de Ciências Agrárias, Programa de Pós-Graduação em Produção Sustentável e Saúde Animal, Umuarama, Paraná, Brasil.

${ }^{2}$ Universidade Federal da Grande Dourados, Faculdade de Ciências Agrárias, Departamento de Zootecnia, Dourados, Mato Grosso do Sul, Brasil.

${ }^{3}$ Universidade Estadual de Maringá, Centro de Ciências Agrárias, Departamento de Medicina Veterinária, Umuarama, Paraná, Brasil.

${ }^{4}$ Médico Veterinário, Mestre em Ciência Animal, Umuarama, Paraná, Brasil.

*Endereço para correspondência: jefferson_portuga@hotmail.com
}

\section{SUMMARY}

This study aimed to evaluate the rumen degradability of dry matter (DM), disappearance of neutral detergent fiber (NDF) of Tifton 85 hay, and fermentation parameters $(\mathrm{pH}$ and ruminal ammonia nitrogen) of sheep fed diets with inclusion of safflower grains $(0,7.50$ and $15 \%)$.Three mixed breed lambs with average body weight of $35.50 \pm 1.50 \mathrm{~kg}$ were used. The rumen degradability of dry matter and NDF of the Tifton 85 haywas analyzedby the disappearance of DM and NDF, and the kinetic parameters adjusted according to the first order asymptotic model. The samples were incubated in the rumen in descending order (96, 48, 24, 12, 6, 3, 0 hours). The determination of ruminal $\mathrm{pH}$ and ruminal ammonia nitrogen (RAN) was performed before feeding and 2, 4, 6 and 8 hours after feeding. Data of ruminal fermentation were tested by analysis of variance with repeated measures in time, at 5\% probability. Ruminal $\mathrm{pH}$ values were not statistically different. When evaluating the RAN, there was a significant difference between the times and treatments for the diet with $15 \%$ safflower. The diets presented low effective degradability of DM and NDF with mean values of $18.02 \%$ and $47.40 \%$, respectively. The safflower grain can be used up to $7.50 \%$ in the diets without altering the degradability and ruminal fermentation.
Keywords: Carthamus tinctorius, degradation kinetics, chemical composition, oilseeds, ruminants

\section{RESUMO}

No presente trabalho objetivou-se avaliar a degradabilidade ruminal da matéria seca (MS), o desaparecimento da fibra de detergente neutro (FDN) do feno de Tifton 85, e os parâmetros de fermentação ( $\mathrm{pH}$ e nitrogênio amoniacal ruminal) de ovinos alimentados com a inclusão de grãos de cártamo $(0,7,50$ e $15 \%)$ na dieta. Foram utilizados 3 cordeiros SRD (sem raça definida) com peso vivo médio de $35,50 \pm 1,50 \mathrm{~kg}$. A degradabilidade ruminal da matéria seca e da FDN do feno de Tifton 85, foi realizada através do desaparecimento de MS e FDN, e os parâmetros cinéticos de degradação ajustados conforme modelo assintótico de primeira ordem. As amostras foram incubadas no rúmen em ordem decrescente (96, 48, 24, 12, 6, 3 e 0 horas). A determinação do $\mathrm{pH}$ ruminal e nitrogênio amoniacal ruminal (NAR) foi realizada antes da alimentação, 2, 4, 6 e 8 horas após alimentação. Os dados de fermentação ruminal foram submetidos à análise de variância através de medidas repetidas no tempo, a $5 \%$ de probabilidade. Os valores de $\mathrm{pH}$ ruminal não houve diferença estatística. Ao avaliar o NAR, houve diferença significativa entre os tempos e tratamentos para a dieta de $15 \%$ de 
inclusão de cártamo. As dietas apresentaram baixa degradabilidade efetiva da MS e FDN com valores médios de $18,02 \%$ e $47,40 \%$, respectivamente. O grão de cártamo pode ser utilizado até $7,50 \%$ nas dietas, sem alterar a degradabilidade e a fermentação ruminal.

Palavras-chave: Carthamus tinctorius, cinética de degradação, composição química, oleaginosas, ruminantes

\section{INTRODUCTION}

Safflower (Carthamus tinctorius L.) is an annual cycle oilseed of the family Asteraceae, which adapts well to various types of soils and climates, mainly the semi-arid. Originating in Asia, it is mainly grown for oil extraction, since about $90 \%$ of its oil is unsaturated (CAMPANELLA et al., 2014). It has tolerance to water deficit, but factors such as temperature and photoperiod decrease its production (SAMPAIO, 2016).

Safflower can be used for several segments such as cooking, paint manufacturing, biodiesel (CORONADO, 2010) and also for ruminant feed, because it has high content of lipids rich in linoleic acid $(76.48 \%)$ and oleic acid (12.93\%) and protein; these nutrients have high cost and are essential for the maintenance and development of the animals (CORREIA et al., 2011).

Thus, safflower becomes an additional option in ruminant feeding, especially in sheep farming, which tends to increase due to the organization of the sector in the domestic market and the tendency of growth in the area in a promising way (POLI et al., 2008), leaving the activity more interesting to the producer, favoring the entry of new breeders (SOUZA et al., 2016).

In ruminants, oil seeds have a characteristic of releasing their oil slowly in the ruminal environment, due to chewing (GOES et al., 2011), favoring a longer time of energy availability, thus reducing oscillations in the ruminal environment. However, the amount to be used may be a decisive factor for the maximum efficiency of the ruminal microorganisms (CANOVA et al., 2015). It is known that the excess of oil in the diet decreases the digestibility due to the difficulty of attachment of the bacteria to the fibers and alters the microbiota by the toxic effect of the unsaturated fatty acids (BASSI et al., 2012). Therefore, in order for the food to be used efficiently, it is necessary to synchronize several factors in the digestive tract such as: $\mathrm{pH}$, temperature, anaerobiosis, substrate and rate of passage of food through the digestive tract. To evaluate the ruminal environment, it is necessary to evaluate ruminal parameters such as ruminal $\mathrm{pH}$ and ammonia nitrogen and dry matter degradability (LIMA, 2008). Therefore, the goal of this study was to evaluate thein situ degradability of the dry matter of Tifton 85 hay and the ruminal parameters in diets with inclusion of increasing levels of safflower grain.

\section{MATERIAL AND METHODS}

The experiment was carried out at the State University of Maringá - Regional Campus of Umuarama - FAZENDA, located at Estrada da Paca, s/n - Jardim São Cristóvão, Umuarama, State of Paraná, (-23.797165 -53.252904). This experiment was conducted according to the Ethics Committee on the Use of Animals, belonging to the Federal University of Grande Dourados, according to opinion number 021/2012 CEUA/UFGD.

Three male, castrated, mixed breed sheep with an initial average weight of $35.5 \pm 1.50 \mathrm{~kg}$, provided with ruminal 
cannula, were kept in individual stalls $(3 \times 6 \mathrm{~m})$ with trough and drinking fountain. Animals were clinically healthy and dewormed as a result of the EPG test performed periodically. The animals received water and feed ad libitum.
The diets were composed of Tifton 85 hay, corn, soybean meal, mineral salt and safflower grain. Diets were formulated according to the requirements of NRC (2007) to be isonitrogenous, based on the chemical composition of the ingredients according to Table 1.

Table 1. Chemical composition of the experimental diet ingredients based on the $\% \mathrm{DM}$, used in sheep feed

\begin{tabular}{lcccccc}
\hline Ingredients & DM & EE & MM & CP & NDF & ADF \\
\hline Corn & 88.20 & 1.50 & 0.10 & 8.20 & 8.99 & 5.37 \\
Soybean meal & 89.70 & 1.30 & 0.30 & 46.60 & 13.84 & 9.49 \\
Safflower grain & 90.35 & 26.00 & 2.80 & 14.79 & 71.19 & 42.11 \\
Tifton85hay & 90.14 & 1.55 & 6.40 & 10.79 & 77.18 & 38.72 \\
\hline
\end{tabular}

$\mathrm{DM}=$ dry Matter, $\mathrm{CP}=$ crude Protein, $\mathrm{EE}=$ ether Extract, $\mathrm{NDF}=$ neutral Detergent Fiber, $\mathrm{ADF}=$ acid Detergent Fiber, $\mathrm{MM}=$ mineral Matter.

Safflower grains were included in the diets at the proportions of $0,7.50$ and $15 \%$ (Table 2). The forage: concentrate ratio used on a dry matter basis was 20:80. The Tifton 85 hay supplied to the animals was previously ground in a Forage Crusher TRF-700 Trapp Jaraguá do Sul, State of Santa Catarina, with a $3 \mathrm{~mm}$ sieve.

Table 2. Percentage composition and chemical composition of experimental diets used in sheep feed

\begin{tabular}{lccc}
\hline \multirow{2}{*}{ Percentage composition (\%) } & \multicolumn{3}{c}{ Safflower levels } \\
\cline { 2 - 4 } Corn & 0.0 & 7.50 & 15.0 \\
Soybean meal & 58.98 & 54.40 & 49.83 \\
Safflower grain & 16.02 & 13.10 & 10.17 \\
Tifton 85hay & 0.00 & 7.50 & 15.00 \\
Mineral mixture & 20.00 & 20.00 & 20.00 \\
\hline Chemical composition (\%DM) & 5.00 & 5.00 & 5.00 \\
\hline Dry matter & & & \\
Crude protein & 84.42 & 84.54 & 84.65 \\
Ether extract & 14.46 & 13.83 & 13.20 \\
Neutral detergente fiber & 1.40 & 3.25 & 5.09 \\
Acid detergente fiber & 22.96 & 27.48 & 32.00 \\
Mineral matter & 12.43 & 15.07 & 17.70 \\
Non-fiber carbohydrates & 1.39 & 1.67 & 1.86 \\
Total carbohydrates & 59.79 & 53.78 & 47.85 \\
Total digestible nutrients & 82.75 & 81.25 & 79.85 \\
\hline O.0 & 77.90 & 75.32 & 72.73 \\
\hline
\end{tabular}

$0.0=$ no safflower grain in the diet; $7.50=7.50 \%$ inclusion of safflower in the diet, $15.0=15 \%$ inclusion of safflower in the diet. 
To calculate the feed supply, it was provided so that there was approximately $10 \%$ leftover in the trough. Initially, $3 \%$ dry matter was supplied in relation to body weight, divided into two meals (8:00 hours and 16:00 hours). The next day in the morning, if there was no leftover in the trough, the provision of feed was increased by $10 \%$ in relation to the previous day; if there was leftover, it was weighed and subtracted from the total amount of the previous day and increased by a further $10 \%$ in relation to the previous day.

The TDN of the diets was estimated from the equations proposed by Capelle et al. (2001):

$\mathrm{TDN}=91.02-0.571588 * \mathrm{NDF}\left(\mathrm{r}^{2}=\right.$ $0.61)$.

For evaluation of Ruminal Degradation of Dry matter and NDF, Tifton 85 hay was ground in knife mill with $3 \mathrm{~mm}$ sieves. NWF bags $\left(100 \mathrm{~g} / \mathrm{cm}^{2}\right), 5 \times 5 \mathrm{~cm}$ in size and were made and individually weighed. The samples were weighed and introduced into the bags in the amount of 0.50 grams of hay per bag, respecting $20 \mathrm{mg} / \mathrm{cm}^{2}$, as recommended by Huntington \& Givens (1995). The NWF bags were placed in cheesecloth bags, with a sinker weighing 87 grams, and introduced directly into the rumen in decreasing order of $96,48,24,12,6$, 3 , and 0 hours. The cheesecloth bag was tied with a $0.8 \mathrm{~m}$ long nylon thread.

The NWF bags were removed all together, immediately placed in a container with water and ice to stop the fermentation and then washed with running water and placed in a ventilated oven at $65^{\circ} \mathrm{C}$ for 48 hours then weighed and stored for determination of disappearance of DM and NDF.

The disappearance of DM and NDF was based on the weight difference between the incubated material and the recovered material after incubation, and the adjusted degradation curves using PROC NLIN SAS 9.2.

For the determination of fermentation kinetic parameters, the first-order asymptotic model proposed by Orskov \& McDonald (1979) was applied by using the formula:

$$
P D=a+b\left(1-e^{-c t}\right)
$$

where $\mathrm{PD}=$ potential rumen degradability of food; $a=$ soluble fraction; $b=$ potential degradable fraction of the insoluble fraction that would be degraded at a rate $c ; c=$ degradation rate of fraction " $b$ "; $t=$ incubation time in hours.

The fraction considered undegradable was considered as: $\mathrm{I}=(100-(\mathrm{a}+\mathrm{b}))$. To evaluate the effective degradability (ED), it was calculated with the mathematical model:

$$
\mathrm{ED}=\mathrm{a}+[(\mathrm{b} * \mathrm{c}) /(\mathrm{c}+\mathrm{K})]
$$

where $\mathrm{K}=$ rate of passage of solids through the rumen, defined here as $2 \% / \mathrm{h}, 5 \% / \mathrm{h}$ and $8 \% / \mathrm{h}$, and related to the level of low, medium and high food intake, respectively.

The disappearance value found at time zero ("a") was used to estimate the colonization time (CT) for DM and NDF, according to Goes et al. (2017), where the parameters "a", "b", and "c" were evaluated by the Gaus Newton algorithm: $\mathrm{CT}=\left[-\ln \left(\mathrm{a}^{\prime}-\mathrm{a}-\mathrm{b}\right) / \mathrm{c}\right]$.

The foods were dried and processed in a Wiley mill with a $1 \mathrm{~mm}$ sieve and stored in plastic bottles; and transported to the Laboratory of Animal Nutrition, for determination of dry matter (method 930.15); crude protein (method 976.05) according to the methodologies described by AOAC (2006). For the NDF analyses, the samples were treated with solution devoid of sodium sulfite and corrected for ash (MERTENS, 2002). 
For the determination of NDF, we used the fiber determinator Tecnal ${ }^{\circledR}$ model TE149 - Piracicaba, State of São Paulo. The samples were treated with thermostable alpha-amylase without sodium sulfite and corrected for ash as described by Mertens (2002).

To evaluate ruminal $\mathrm{pH}$ and $\mathrm{RAN}$, ruminal fluid samples were collected at the times: 0 (before feeding), 2, 4, 6, and 8 hours after feeding in triplicate. Approximately $100 \mathrm{~mL}$ ruminal fluid was collected at the specific times, filtered and measured in a digital $\mathrm{pH}$ meter of alpax, model APA 200 -Diadema, State of São Paulo.

For the determination of RAN, after collection of ruminal fluid, a $40 \mathrm{~mL}$ aliquot was separated and $1 \mathrm{~mL}$ hydrochloric acid was added, then centrifuged and taken $4 \mathrm{~mL}$ serum and stored in two Eppendorf tubes. The

$$
\mathrm{Y} \mathrm{Y}_{\mathrm{ijk}}=\mu+\mathrm{Q}_{1}+\mathrm{A}_{\mathrm{i}}+\mathrm{P}_{\mathrm{j}}+\mathrm{D}_{\mathrm{k}}+\mathrm{T}_{\mathrm{y}}+\mathrm{T}_{\mathrm{y}}\left(\mathrm{D}_{\mathrm{k}}\right)+\mathrm{e}_{\mathrm{ijk} \mathrm{l}}
$$

where: $Y_{\mathrm{ijyk}}=$ observation of animal $\mathrm{i}$, in period $\mathrm{j}$, subjected to dose $\mathrm{k}$, in time $\mathrm{y}$, in the square $1 ; \mu=$ overall mean, $\mathrm{Q}_{1}=$ random effect of square $1(1=1$ to 2$) ; A_{i}=$ random effect of animal ( $\mathrm{i}=1$ to 3 ), $\mathrm{Pj}=$ random effect of period ( $\mathrm{j}=1$ to 3$), \mathrm{D}_{\mathrm{k}}=$ fixed effect of dose used ( $\mathrm{k}=1$ to 3$)$, Ty $=$ fixed effect of collection time $(\mathrm{k}=1$ to 5), $\mathrm{T}_{\mathrm{y}}\left(\mathrm{D}_{\mathrm{k}}\right)=$ interaction between doses used and collection time, and $\mathrm{e}_{\mathrm{ijkl}}=$ random effect of error, associated with each observation, assuming that NID $(0$; $\sigma^{2}$ ).

Data were tested by analysis of variance and polynomial regression, adopting a level of significance of $5 \%$.

\section{RESULTS AND DISCUSSION}

Tifton 85 hay presented low effective degradability (Table 3 ), regardless of the samples were frozen at $-18^{\circ} \mathrm{C}$ for future evaluation, and this methodology was performed as described by Detmann et al. (2012).

Data obtained from ruminal fermentation were analyzed in a $3 \times 3$ Latin square design, repeated in time, using the REPEAT command of PROC MIXED, SAS 9.2, using the covariance matrices: compound symmetry (CS); heterogeneous compound symmetry (CSH); first order autoregressive (AR1); first-order heterogeneous autoregressive (ARH1); Toeplitz (TOEP); heterogeneous Toeplitz (TOEPH); analytical factor (FA); Huynh-Felt (HF); unstructured (UN) and components of variance (CV). The variance and variance matrices were evaluated by means of SBC criteria (Schawrz's Bayesian Criterion).

The mathematical model adopted was: level of safflower used, with values for the soluble fraction of $8.09,8.77$ and 6.03 for $0,7.50$ and $15 \%$ inclusion levels, respectively. These values are explained by the high content of ether extract in the diet, which makes it difficult the attachment of the ruminal bacteria (OLIVEIRA et al., 2009) and the high concentration ( $80 \%$ concentrate and $20 \%$ forage) of concentrate in the diet. Fortaleza et al. (2009) also found low dry matter degradability using cotton seed. The lowest soluble fraction presented by the hay to the $15 \%$ inclusion level of safflower provided a potential degradability of $24.09 \%$, as in Figure 1 and effective degradability of $26.13 \%$ (Table 3). The inclusion of safflower showed a "c" degradation rate of $1.51 \% / \mathrm{h}$, a reduction of $47.20 \%$, which probably interfered with the lower values of hay degradation for the diets added with safflower. The inclusion of safflower 
grains in sheep diet reduces the degradability of the dry matter, with reduction of the soluble fraction and the degradation rate; this low degradability decreases the level of ammonia nitrogen, interfering with the microbial synthesis. Santos et al. (2012) also found low effective degradability using sunflower cake.

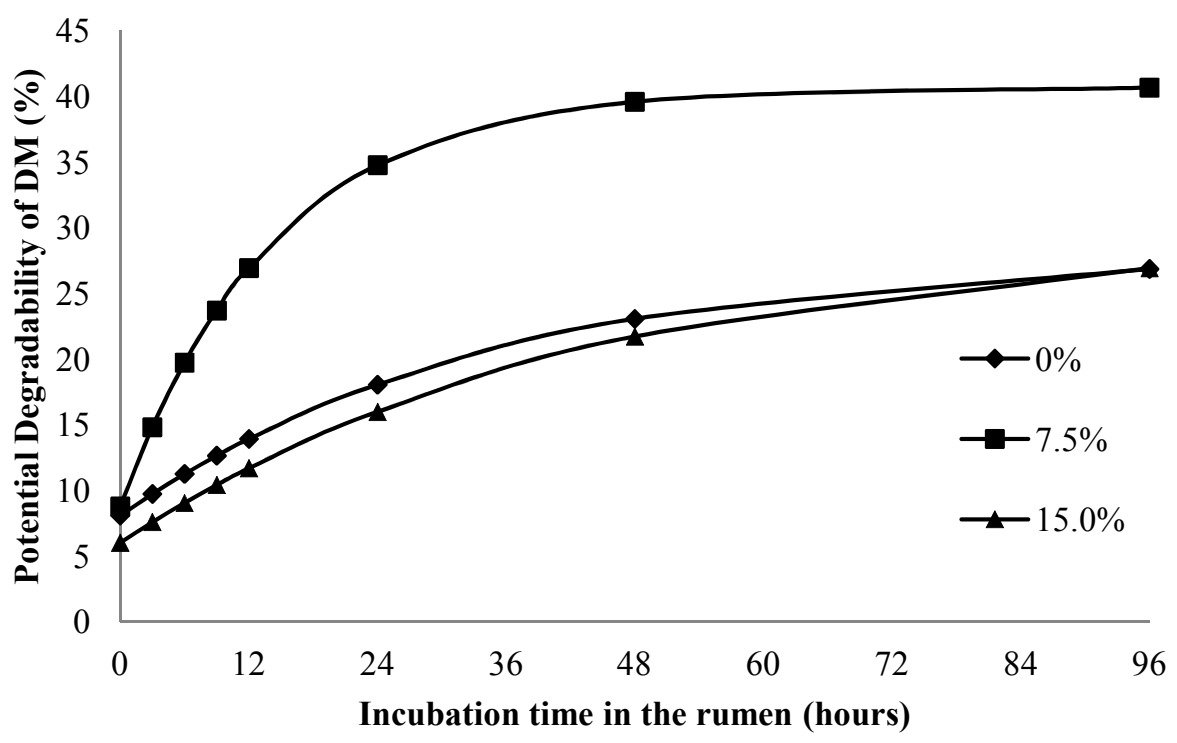

Figure 1. Illustration of the potential degradability of dry matter in $\%$ in different collection times and treatments

Table 3. Kinetic parameters and effective degradability of Tifton 85 hay dry matter in different levels of safflower inclusion

\begin{tabular}{|c|c|c|c|c|c|c|c|c|c|}
\hline \multirow{2}{*}{$\begin{array}{l}\text { DM } \\
\% \text { Safflower }\end{array}$} & \multicolumn{4}{|c|}{ Parameters* } & \multicolumn{4}{|c|}{ Effective Degradability $(\% / \mathrm{h})$} & \multirow{2}{*}{ CT (h) } \\
\hline & $\mathrm{a}(\%)$ & $\mathrm{b}(\%)$ & $\mathrm{c}(\%)$ & $\mathrm{I}(\%)$ & 2 & 5 & 8 & $\mathrm{r}^{2}$ & \\
\hline $0 \%$ & 5.16 & 49.97 & 3.50 & 44.87 & 36.96 & 25.74 & 20.37 & 0.40 & 7.26 \\
\hline $7.5 \%$ & 4.92 & 40.00 & 3.80 & 55.08 & 31.13 & 22.19 & 17.80 & 0.40 & 6.96 \\
\hline $15 \%$ & 4.96 & 39.99 & 9.00 & 55.05 & 37.68 & 30.67 & 26.13 & 0.55 & 6.10 \\
\hline
\end{tabular}

$\mathrm{a}=$ soluble fraction; $\mathrm{b}=$ potentially degradable fraction; $\mathrm{c}=$ degradation rate of fraction $\mathrm{b} ; \mathrm{CT}=$ colonization time.

The potential degradability of NDF was $53.39,43.88$ and $44.94 \%$ for the diets 0 , 7.50 and $15 \%$, respectively (Figure 2); these results were low and could be explained by the high content of oil in the diet, which interferes with the solubilization of compounds during NDF determination (SILVA \& QUEIROZ, 2002), and also because the concentration of ruminal ammonia nitrogen was below the values of maximum microbial efficiency, since the ruminal microorganisms depend on RAN forits synthesis.

NDF is one of the parameters that regulates intake, rumination and passage rate of DM (ALVES et al., 2016). According to Geron et al. (2013), the greater the proportion of concentrate in the diet the lower the intake of NDF. Hay 
presented high NDF $(77.18 \%)$ and ADF $(38.72 \%)$ contents, which favored low degradability. Another factor that interfered with the degradability was the high proportion of forage: concentrate used in the diet, due to the high supply of non-soluble carbohydrates (SALCEDO et al., 2016).

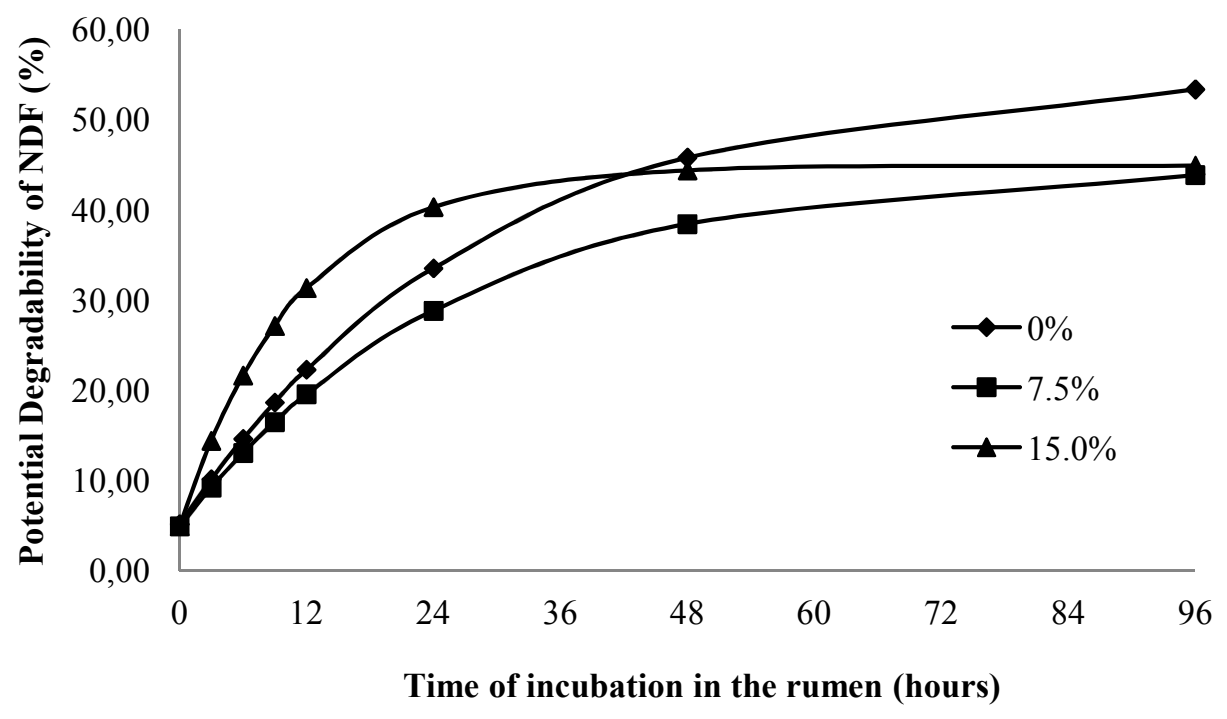

Figure 2. Illustration of the disappearance of NDF in $\%$ in different collection times and treatments

No effect was detected for the addition of safflower, time and interaction, for $\mathrm{pH}$ (Table 4), which presented mean values of $6.54,6.24$ and 6.70 for treatments 0,7 , 50 and $15 \%$, respectively. Silva (2014) also observed no difference in ruminal $\mathrm{pH}$ using sunflower cake.

The treatments using $0,7.5$ and $15 \%$ safflower started with $\mathrm{pH} 6.63,6.55$ and
7.03 (Figure 3), respectively, these values are higher compared to the subsequent times of collection evaluated due to the low availability of nutrients present in the rumen and stimulation of rumination in animals (MOREIRA et al., 2009).

Table 4. Parameters of ruminal fermentation of sheep fed increasing levels of safflower grains in the diet

\begin{tabular}{|c|c|c|c|c|c|c|c|}
\hline \multirow{2}{*}{ Item } & \multicolumn{3}{|c|}{ Experimental diets } & \multirow{2}{*}{ SEM } & \multicolumn{3}{|c|}{ P-value } \\
\hline & 0 & 7.50 & 15 & & Source & Time & Interaction \\
\hline $\mathrm{pH}$ & 6.54 & 6.24 & 6.70 & 0.05 & 0.265 & 0.007 & 0.715 \\
\hline $\mathrm{N}-\mathrm{NH}_{3} *$ & $17.70^{\mathrm{a}}$ & $15.65^{\mathrm{a}}$ & $7.79^{b}$ & 0.83 & $<0.001$ & 0.001 & 0.340 \\
\hline
\end{tabular}

$* \mathrm{y}=-0.051 \mathrm{x}^{2}+0.114 \mathrm{x}+17.7, \mathrm{r}^{2}=0.90$.

Means followed by the same letters do not differ from each other by the Tukey's test at $5 \%$. 


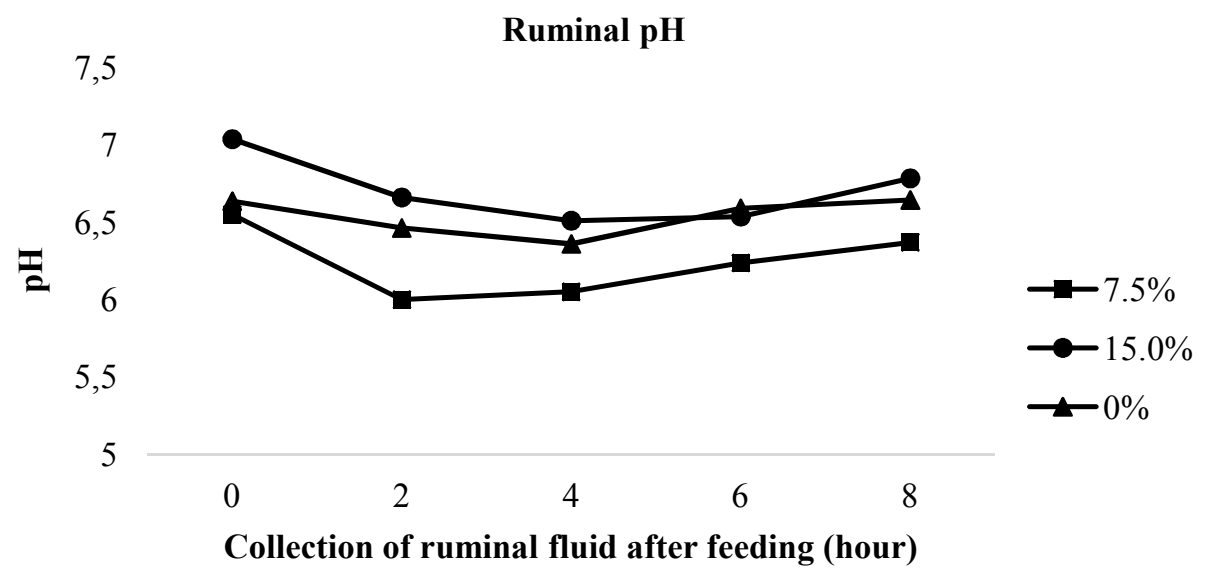

Figure 3. Ruminal $\mathrm{pH}$ estimation according to the treatments and the collection time in hours

According to Figure 4, the mean ruminal $\mathrm{pH}$ data ranged from 6.74 to 6.31 , between the time 0 (before feeding) and 4 hours, after feeding, respectively, due to the rapid fermentation of carbohydrates in the rumen, increased production of volatile fatty acids (VFA) and decreased salivation due to a shorter rumination time, resulting in a drop in $\mathrm{pH}$ (SANTOS et al., 2014). This decrease in $\mathrm{pH}$ may be associated with the peak of the ammonia concentration in the ruminal environment 2 hours after feeding, this increase can be explained by the lower $\mathrm{pH}$ that decreases the ammonia absorption by the rumen and/or because the ruminal $\mathrm{pH}$ has decreased the microbial growth and the ammonia has not been used (SANTOS et al., 2012). There is an antagonism between ruminal $\mathrm{pH}$ and ruminal ammonia nitrogen, the lower the $\mathrm{pH}$, the higher the RAN concentration available, because $\mathrm{pH}$ decreases bacterial growth and consequently there will be a decrease in the use of RAN by microorganisms.

For a favorable environment for bacterial proliferation, fiber digestion and growth of cellulolytic bacteria, it is necessary that the $\mathrm{pH}$ is not below 6 nor above 7.20. Furtado et al. (2014) analyzed the inclusion of castor bean cake and obtained $\mathrm{pH}$ values between 6.43 and 6.92 , also within the ideal range for the proper functioning of the rumen.

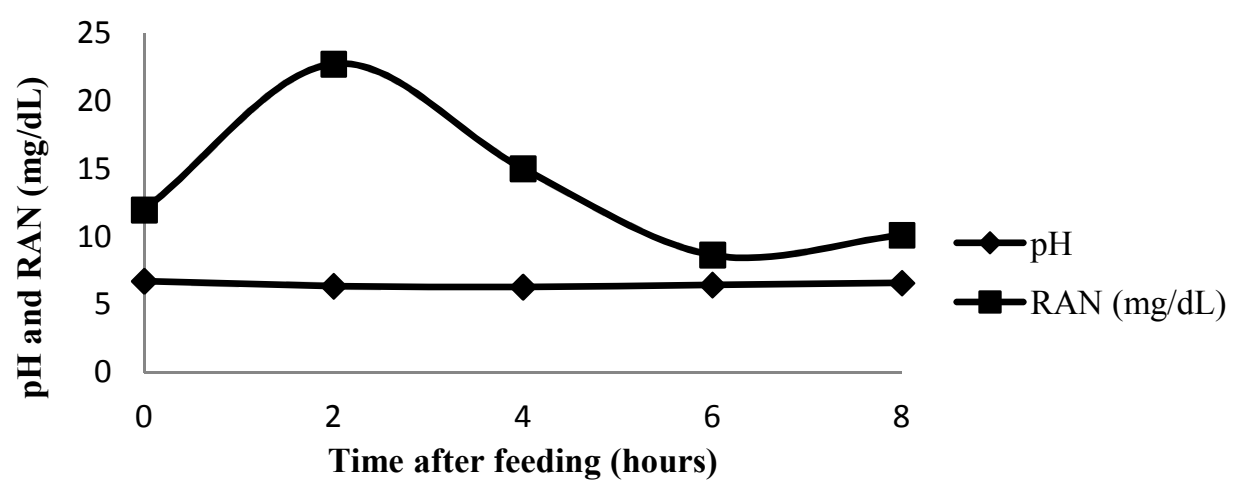

Figure 4. Mean values of the treatments for ruminal $\mathrm{pH}$ and ruminal ammonia nitrogen in the different collection times 
According to Santos et al. (2012), in feed balancing, two requirements can have a great impact on ruminal $\mathrm{pH}$, the concentration of non-fiber carbohydrates and the concentration of ether extract that should not be above $6 \%$ DM, which did not occur in this experiment. There was no significant difference in ammonia concentration between treatments $0 \%$ and $7.5 \%$, but these treatments differed from the $15 \%$ safflower diet, where the mean RAN concentration was $17.70,15.65$ and $7.79 \mathrm{mg} / \mathrm{dL}$ for treatments $0,7.5$ and $15 \%$, respectively (Figure 5). There was also a significant difference between the times corroborating Furtado et al. (2014), who used castor bean cake in the diet. As shown in Figure 9, in all collections, values of $\mathrm{NH}_{3}-\mathrm{N} \mathrm{mg} / \mathrm{dL}$, for the $0 \%$ and $7.5 \%$ treatments values were higher than $7.79 \mathrm{mg} / \mathrm{dL}$. However, the $15 \%$ treatment obtained a value of $4.91 \mathrm{mg} / \mathrm{dL}$ of $\mathrm{NH}_{3}-\mathrm{N}$ for the time 6 hours after feeding, impairing the protein synthesis. The ammonia nitrogen peak with 2 hours after feeding occurs due to the increase of available nutrients in the rumen and the decrease in $\mathrm{pH}$. According to Furtado et al. (2014), there was a significant difference in RAN concentration between the collection times of the ruminal fluid, due to the increase in the protein concentration rate and the balance of the microbiota in the use of the same when the food is introduced.

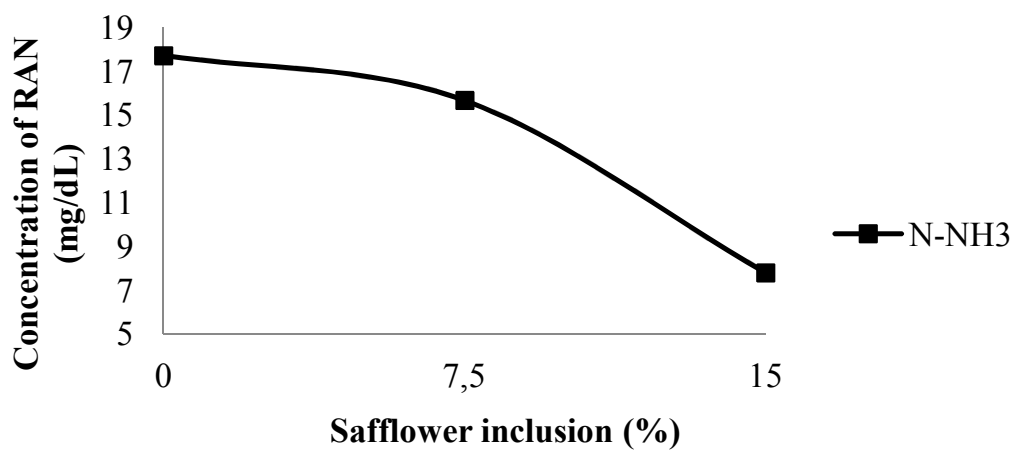

Figure 5. Mean concentration of ruminal ammonia nitrogen according to the treatments

The mean value of $\mathrm{NH}_{3}-\mathrm{N}$ content of the ruminal fluid was $18.07,18.98$ and 9.39 $\mathrm{mg} / \mathrm{dL}$ for the diets $0 \%, 7.50 \%$ and $15 \%$ safflower respectively. These values are below the values ideal for maximum ruminal fermentation efficiency, according to Zeoula et al. (1999). The safflower grain at $7.5 \%$ concentration in the diet can be used to feed sheep, as there was no negative change in the parameters evaluated. The level of $15 \%$ inclusion of safflower grain in the diet is not recommended, due to the decrease in the concentration of ruminal ammonia nitrogen.

\section{ACKNOWLEDGEMENTS}

To the Coordination for the Improvement of Higher Education Personnel - CAPES; Federal University of Grande Dourados and the State University of Maringá-UEM, for financial support and scholarships. To the Research Support Foundation of the State of Mato Grosso do Sul (FUNDECT) and the National Council for Scientific and Technological Development (CNPq) for financing part of this work. To Prof. Dr. Luis Carlos Ferreira de Souza, for donating the safflower used in the research. 


\section{REFERENCES}

ASSOCIATION OF OFFICIAL ANALYTICAL CHEMISTS - AOAC. Official Methods of Analysis. 18th.ed. Arlington, VA, 2006.

ALVES, A.R.; PASCOAL, L.A.F.; CAMBUI, G.B.; TRAJANO, J.S.; SILVA, C.M.; GOIS, G.C. Fibra para ruminantes: aspecto nutricional, metodológico e funcional. Pubvet, v.10, n.7, p.568-579, 2016.

BASSI, M.S.; LADEIRA, M.M.; CHIZZOTTI, M.L.; CHIZZOTTI, F.H.M.; OLIVEIRA, D.M.; NETO, O.R.M; CARVALHO, J.R.R.; NOGUEIRA NETO, A.A.N. Oilseeds in zebu cattle diet: intake, digestibility and performance. Revista Brasileira

Zootecnia, v.41, n.2, p.353-359, 2012.

CANOVA, É.B.; BUENO, M.S.; MOREIRA, H.L.; POSSENTI, R.; BRÁS, P. Crambe cake (Crambe abyssinica Hochst) on lamb diets.

Ciência e Agrotecnologia, v.39, p.75-81, 2015.

CAPELLE, E.R.; VALADARES FILHO, S.C.; SILVA, J.F.C.; CECON, P.R. Estimates of the Energy Value from Chemical Characteristics of the Feedstuffs. Revista Brasileira de Zootecnia, v.30, p.1837-1856, 2001.

CAMPANELLA, L.C.A.; SILVA, A.C.; FREYGANG, J.; DAL MAGRO, D.D. Efeito da suplementação de óleo de cártamo sobre o peso corporal, perfil lipídico, glicídico e antioxidante de ratos wistar induzidos a obesidade.

Revista de Ciência Farmacêuticas Básica e Aplicada, v.35, n.1, p.141147, 2014.
CORONADO, L.M. El cultivo del cártamo (Carthamus tinctorius L.) en México. Ciudad Obregon, México: SGI, 2010. 96p.

CORREIA, B.R.; OLIVEIRA, R.L.; JAEGER, S.M.P.L.; BAGALDO, A.R.; CARVALHO, G.G.P.; OLIVEIRA, G.J.C.; LIMA, F.H.S.; OLIVEIRA, P.A. Intake, digestibility and ruminal $\mathrm{pH}$ of steers fed diets with pies coming from the production from biodiesel to replacement soybean meal. Arquivo Brasileiro de Medicina Veterinária e Zootecnia, v.63, p.356-363, 2011.

DETMANN, E.; SOUZA, M.A.;VALADARES FILHO, S.C.; QUEIROZ, A.C.; BERCHIELLI, T.T.; SALIBA, E.O.S.; CABRAL, L.S.; PINA, D.S.; LADEIRA, M.M.; AZEVEDO, J.A.G. (Eds.) Métodos para análise de alimentos. Visconde do Rio Branco: Suprema, 2012. 214p.

FORTALEZA, A.P.S.; SILVA, L.D.F.; RIBEIRO, E.L.A; BARBERO, R.P; JUNIOR, F.L.M.; SANTOS, A.X.; CASTRO, V.S.; CASTRO, F.A.B. Degradabilidade ruminal in situ dos componentes nutritivos de alguns suplementos concentrados usados na alimentação de bovinos. Semina: Ciências Agrárias, v.30, n.2, p.481496, 2009.

FURTADO, R.N.; CARNEIRO, M.S.S.; CANDIDO, M.J.D.; GOMES, F.H.T.; ROGERIO, M.C.P.; SILVA, D.S. Balanço de nitrogênio e avaliação ruminal em ovinos machos e fêmeas alimentados com rações contendo torta de mamona sob diferentes tratamentos. Revista Ciências Agrárias, v.35, n.6, p.3237-3248, 2014. 
GERON, L.J.V.; MEXIA, A.A.; CRISTO, R.L.; GARCIA, J.; CABRAL, L.S.; TRAUTMANN, R.J.; ZEOULA, E.S.M. Consumo, digestibilidade dos nutrientes e características ruminais de cordeiros alimentados com níveis crescentes de concentrado em ambiente tropical no Vale do Alto Guaporé - MT. Ciências Agrárias, v.34, n.5, p.24972510, 2013.

GOES, R.H.T.B.; PATUSSI, R.A.; GANDRA, J.R.; BRANCO, A.F.; CARDOSO, T.J.L.; OLIVEIRA, M.V.M.; OLIVEIRA, R.T.; SOUZA, C.J.S. The crambe (Crambe abyssinica Hochst) byproducts, can be used as a source of non-degradable protein in the rumen? Bioscience Journal, v.33, p.113120, 2017.

GOES, R.H.T.B.; SOUZA, K.A.; NIGUEIRA, K.A.G.; PEREIRA, D.F.; OLIVEIRA, E.R.; BRABES, K.C.S. Degradabilidade ruminal da matéria seca e proteína bruta, e tempo de colonização microbiana de oleaginosas, utilizadas na alimentação de ovinos. Acta Scientiarum. Animal Sciences, v.33, n.4, p.373-378, 2011.

HUNTINGTON, J.A.; GIVENS, D.I. The in situ technique for studying the rumen degradation of feeds: A review of the procedure. Nutrition Abstrats and Reviews, Series B, v.65, n.2, p.63-90, 1995.

LIMA, M.L.M. Padrão de Fermentação Ruminal de Bovinos Recebendo Produto Homeopático. Ciência Animal Brasileira, v.9, n.4, p.969-975, 2008.

MERTENS, D.R. Gravimetric determination of amylase-treated neutral detergent fiber in feeds with refluxing in beaker or crucibles: collaborative study. Journal of AOAC International, v.85, p.1217-1240, 2002.
MOREIRA, P.C.; MENDONÇA, A.C.; MARTINS, A.F.; WASCHECK, R.C.; SOUZA, P.R.; DUTRA, A.R.; GRANDSIRE, C.; REZENDE, P.L.P.; CARDOSO, J.R.; BENETTI, E.J.; SILVA, M.S.B. Avaliação do $\mathrm{pH}$ do fluido ruminal de vacas leiteiras. Estudos, v.36, n.11/12, p.1201-1218, 2009.

NATIONAL RESEARCH COUNCIL NRC. Nutrient requirements of small ruminants: sheep, goats, cervids, and new world camelids. Washington, D.C.: National academy Pres, 2007. 362p.

OLIVEIRA, R.L.; BAGALDO, A.R.; LADEIRA, M.M.; BARBOSA, M.A.A de. F.; OLIVEIRA, R. L. de.; JAEGER, S.M.P.L. Fontes de lipídeos na dieta de búfalas lactantes: consumo, digestibilidade e N-uréico plasmático. Revista Brasileira Zootecnia, v.38, n.3, p.553-559, 2009.

ORSKOV, E.R.; McDONALD, J. The estimation of protein degradability in the rumen from incubation measurements weighted according to rate of passage. Journal of Agricultural Science, v.92, n.1, p.499-503, 1979.

POLI, C.H.E.C.; MONTEIRO, A.L.G.; BARROS, C.S.; MORAES, A.; FERNANDES, M.A.M.; PIAZZETTA, H.V.L. Produção de ovinos de corte em quatro sistemas de produção. Revista Brasileira de Zootecnia, v.37, n.4, p.666-673, 2008.

\section{SAMPAIO, M.C. Cultivo de Cártamo}

(Carthamus Tinctorius L.) sob variação de adubações, densidades e épocas de plantio. 2006. 63p. Dissertação (Mestrado) - Universidade Estadual do Oeste do Paraná, Programa de PósGraduação Stricto Sensu em Engenharia de Energia na Agricultura. Cascavel. 
SANTOS, V.C.; EZEQUIEL, J.M.B.; MORGADO, E S.; JUNIOR, A.C.H.; FÁVARO, V.R.; D'AUREA, A.P.; SOUZA, S.F.; BARBOSA, J.C. Influência de subprodutos de oleaginosas sobre parâmetros ruminais e a degradação da matéria seca e da proteína bruta. Arquivo Brasileiro de Medicina Veterinária e Zootecnia, v.64, n.5, p.1284-1291, 2012.

SANTOS, V.C.; EZEQUIEL, J.M.B.; MORGADO, E.S.; FAVARO, V.R.; D'AUREA, A.P.; JUNIOR S.C.S. Desempenho e digestibilidade de componentes nutritivos de dietas contendo subprodutos de oleaginosas na alimentação de cordeiros. Semina:

Ciências Agrárias, v.35, n.3, p.15771586, 2014.

SALCEDO, Y.T.G.; RIBEIRO JUNIOR, C.S.; CANESIN, R.C. Influencia da relação volumoso: concentrado da dieta no metabolismo ruminal em bovinos de corte. Revista Faculdade Ciencias Agropecuarias. v.8, p.19-24, 2016.

SILVA, D.J.; QUEIROZ, A.C. Análise de alimentos: métodos químicos e biológicos. Viçosa: Universidade Federal de Viçosa, 2002.

SILVA, L.H.X. Cinética de fermentação ruminal de dietas com coprodutos da cadeia produtiva do biodiesel. 2014. 72f. Dissertação (Mestrado) - Universidade Federal da Grande Dourados, Dourados.

SOUZA, J.D. F.; GUIMARÃES, V.P.; MAGALHÃES, K.A.; BARBOSA, C.M.P.; MARTINS, E.C.; FILHO, Z.F.H.; MENDES, M.E.P. Embrapa Caprinos e Ovinos. Ativos Caprinos e Ovinos, v.3, n.2, p.1-6, 2016.
ZEOULA, L.M.; PRADO, I.N.; CECATO, U. Valor Nutritivo de rações compostas de fonte de amido e de nitrogênio com alta e baixa degradabilidade ruminal. Revista Brasileira de Zootecnia, v.28, n.5, p.1159-1167, 1999.

Receipt date: $26 / 02 / 2018$ Approval date: 22/06/2018 